\title{
Roseovarius halotolerans sp. nov., isolated from deep seawater
}

\author{
Yong-Sik Oh, ${ }^{1}$ Hayung-Joon Lim, ${ }^{1}$ In-Tae Cha, ${ }^{1}$ Wan-Taek Im, ${ }^{2}$ \\ Jae-Soo Yoo, ${ }^{3}$ Ui Gum Kang, ${ }^{4}$ Sung-Keun Rhee ${ }^{1}$ and Dong-Hyun Roh ${ }^{1}$ \\ ${ }^{1}$ Department of Microbiology and Biotechnology Research Institute, Chungbuk National University, \\ Cheongju 361-763, Chungbuk, Republic of Korea \\ ${ }^{2}$ Department of Biological Sciences, Korea Advanced Institute of Science and Technology, 373-1 \\ Guseong-dong, Yuseong-gu, Daejeon 305-701, Republic of Korea \\ ${ }^{3}$ School of Electrical and Computer Engineering, Chungbuk National University, Cheongju 361- \\ 763, Chungbuk, Republic of Korea \\ ${ }^{4}$ Yeongnam Agricultural Research Institute (NICS, RDA), Milyang 627-803, Republic of Korea
}

Correspondence

Dong-Hyun Roh

dhroh@chungbuk.ac.kr
A Gram-reaction-negative, non-motile, aerobic bacterium, designated $\mathrm{HJ}^{\top} \mathrm{O}^{\top}$, was isolated from deep seawater of the East Sea, South Korea. Cells were ovoid to rod-shaped (0.5-0.8×1.3$3.0 \mu \mathrm{m}$ ), often with unequal ends, suggesting a budding mode of reproduction. The strain had an absolute requirement for sea salts and tolerated up to $20 \%(\mathrm{w} / \mathrm{v})$ sea salts. Propionate, DL-lactate, 2-ketogluconate, 3-hydroxybutyrate and rhamnose were used as growth substrates, but not mannitol, salicin, 4-hydroxybenzoate or acetate. The major fatty acid was summed feature 7 $\left(\mathrm{C}_{18: 1} \omega 7 \mathrm{c} / \omega 9 \mathrm{t} / \omega 12 t\right)$ and the DNA G $+\mathrm{C}$ content was $59.0 \pm 0.1 \mathrm{~mol} \%$. Phylogenetic analyses based on 16S rRNA gene sequences showed that this strain was affiliated with the genus Roseovarius. Similarities between the 16S rRNA gene sequence of strain $\mathrm{HJ}^{\top} \mathrm{O}^{\top}$ (1430 nt) and those of type strains of members of the genus Roseovarius were 94.1-96.3\%. DNA-DNA relatedness values between strain $\mathrm{HJ}^{\circ} \mathrm{O}^{\top}$ and the type strains of members of the genus Roseovarius were low (1.3-24.6\%). Physiological and biochemical differences support assignment of strain $\mathrm{HJ}_{50}{ }^{\top}$ to the genus Roseovarius as a representative of a novel species. The name Roseovarius halotolerans sp. nov. is proposed, with $\mathrm{HJ}^{\circ} 0^{\top}\left(=\mathrm{KCTC} 22224^{\top}=\mathrm{LMG}\right.$ $24468^{\top}$ ) as the type strain.
The genus Roseovarius was first created by Labrenz et al. (1999) to accommodate species of the family Rhodobacteraceae that divided by budding and were Gram-negative, aerobic and peroxidase- and catalasepositive. At the time of writing, the genus comprised five recognized species, Roseovarius tolerans (Labrenz et al., 1999), Rva. nubinhibens (González et al., 2003), Rva. crassostreae (Boettcher et al., 2005), Rva. mucosus (Biebl et al., 2005) and Rva. aestuarii (Yoon et al., 2008).

A bacterial strain, designated $\mathrm{HJ} 50^{\mathrm{T}}$, was isolated from 200-500 m deep seawater of the East Sea of Korea using a dilution plating technique on marine agar 2216 plates (MA; Difco). Strain $\mathrm{HJ}_{50}{ }^{\mathrm{T}}$ was grown routinely on marine broth 2216 (MB; Difco), MA and YTSS broth or agar. YTSS broth/agar contained $\left(1^{-1}\right) 5 \mathrm{~g}$ yeast extract, $10 \mathrm{~g}$ tryptone,

The GenBank/EMBL/DDBJ accession number for the 16S rRNA gene sequence of strain $\mathrm{HJ}^{\top} \mathrm{O}^{\top}$ is EU431217.

A TLC showing the polar lipids of strain $\mathrm{HJ}^{\top} \mathrm{O}^{\top}$ is available as supplementary material with the online version of this paper.
$20 \mathrm{~g}$ sea salts (Sigma) and (plates only) $15 \mathrm{~g}$ agar. Cultures were stored at $-80{ }^{\circ} \mathrm{C}$ in $\mathrm{MB}$ supplemented with $25 \%$ (v/v) glycerol. Reference strains Rva. tolerans DSM $11457^{\mathrm{T}}$, Rva. nubinhibens DSM $15170^{\mathrm{T}}$, Rva. crassostreae DSM $16950^{\mathrm{T}}$ and Rva. mucosus DSM $17069^{\mathrm{T}}$ were obtained from the DSMZ (Braunschweig, Germany). For analysis of lipoquinones and fatty acids, strain $\mathrm{HJ} 50^{\mathrm{T}}$ and the type strains of Roseovarius species were grown on MA at $30{ }^{\circ} \mathrm{C}$ for 3 days.

Morphology and cell size were determined by phasecontrast microscopy (Nikon 80i). Gram staining was performed with BD Gram stain kits according to the instructions of the manufacturer and by the non-staining method as described by Buck (1982). Flagellation was examined by transmission electron microscopy using cells grown on MA at $30{ }^{\circ} \mathrm{C}$. A Formvar-coated grid was floated on a droplet of sample on Parafilm for $1 \mathrm{~min}$ to permit adsorption of the specimen. The grid was then transferred onto a drop of negative stain ( $1 \%$ phosphotungstic acid) for $30 \mathrm{~s}$, blotted with filter paper and then air-dried. The 
sample was examined under a CM 20 (Philips) electron microscope. Catalase activity was determined by bubble production in $3 \%(\mathrm{v} / \mathrm{v}) \mathrm{H}_{2} \mathrm{O}_{2}$ and oxidase activity was assessed using oxidase reagent (bioMérieux) according to the manufacturer's instructions after cultivation for 2 days. Acid production from glucose, single-carbon-source assimilations and additional physiological characteristics were determined using the API 20NE and API ID32GN galleries according to the instructions of the manufacturer (bioMérieux) except that the culture was suspended in $3 \%(\mathrm{w} / \mathrm{v})$ sea salts. For reference, the type strains were included in this comparison and all tests were performed under the same conditions. Salt tolerance was measured on YTSS plates containing $0-25 \%(\mathrm{w} / \mathrm{v})$ sea salts (Sigma). Plates were incubated at $30{ }^{\circ} \mathrm{C}$ for 14 days. The temperature range for growth was determined on YTSS plates incubated for 14 days at $0,4,10,15,20,25,30,35,37,40$, 45 and $50{ }^{\circ} \mathrm{C}$. Anaerobic growth was performed in Hungate anaerobic culture tubes containing YTSS broth at 25 and $35{ }^{\circ} \mathrm{C}$ with nitrogen gas. The medium was reduced with $1 \mathrm{mM}$ sodium sulfide and resazurin $\left(1 \mathrm{mg} \mathrm{l}^{-1}\right)$ was used to check anaerobic conditions.

Strain $\mathrm{HJ} 50^{\mathrm{T}}$ grew well on both MA and YTSS agar. Young colonies were small, white and uniformly round. Older colonies were faintly pink in the centre with a characteristic umbonate shape, circular, had entire margins and glistening surfaces and were $1.8-3.0 \mathrm{~mm}$ in diameter after 5 days of cultivation at $30{ }^{\circ} \mathrm{C}$ on MA. Cells were ovoid to rodshaped and $0.5-0.8 \times 1.3-3.0 \mu \mathrm{m}$ in size, often with unequal ends (Fig. 1), suggesting a budding mode of division. Flagella in negatively stained preparations and real motility were not observed but cells occasionally showed a turning motion on the spot. Strain $\mathrm{HJ} 50^{\mathrm{T}}$ could grow in the presence of $0.5-20.0 \%$ sea salts (Sigma) in YTSS medium, with maximum growth observed in $3-4 \%$ sea salts. No growth occurred without addition of sea salts. For the test cultures described below, a concentration of $3 \%$

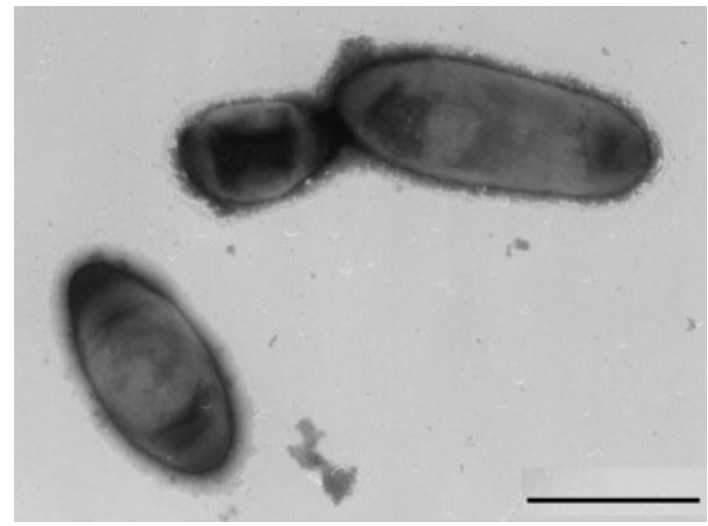

Fig. 1. Negatively stained transmission electron micrograph of cells of strain $\mathrm{HJ}^{\mathrm{N}} \mathrm{O}^{\mathrm{T}}$. Bar, $1 \mu \mathrm{m}$. The dividing cell shows unequal ends, suggesting a budding mode of division. sea salts was used. Within the temperature range tested, the culture developed at $10-45{ }^{\circ} \mathrm{C}$, with maximum growth at $35{ }^{\circ} \mathrm{C}$. Growth was good at initial pH between 6.0 and 10.0, with optimum growth at $\mathrm{pH}$ 7.5. Strain $\mathrm{HJ} 50^{\mathrm{T}}$ was able to hydrolyse aesculin and gelatin and produce urease. Dissimilatory nitrate reduction to either nitrites or nitrogen was not found. Interestingly, strain $\mathrm{HJ}^{5} 0^{\mathrm{T}}$ could utilize propionate, 3-hydroxybutyrate and DL-lactate and produce acid from glucose, thus enabling it to be differentiated from other members of the genus Roseovarius (see Table 1 and the species description for further details). There was no indication of growth under anaerobic conditions for 1 month.

puf $M$ encodes a key polypeptide in the bacterial photosynthetic reaction centre $M$ subunit in various microorganisms (Zeng \& Jiao, 2007; Allgaier et al., 2003). To detect this gene in cells of strain $\mathrm{HJ}^{\mathrm{T}} \mathrm{T}^{\mathrm{T}}$, a pair of primers, pufM.557F and pufM.750R, was used to amplify the pufM gene (Achenbach et al., 2001). PCR was run for 25 cycles with a DNA thermal cycler (MJ Mini; Bio-Rad). The following thermal profiles were used for PCR: predenaturation at $94{ }^{\circ} \mathrm{C}$ for $3 \mathrm{~min}$ and a repeated cycle of denaturation at $94{ }^{\circ} \mathrm{C}$ for $30 \mathrm{~s}$, primer annealing at $60{ }^{\circ} \mathrm{C}$ for $30 \mathrm{~s}$ and extension at $72{ }^{\circ} \mathrm{C}$ for $45 \mathrm{~s}$. The final cycle included an extension at $72{ }^{\circ} \mathrm{C}$ for $10 \mathrm{~min}$. PCR products were separated by electrophoresis on an agarose gel $(3 \%$, $\mathrm{w} / \mathrm{v}$ ) and stained with ethidium bromide. Band size was determined by comparison with a $100 \mathrm{bp}$ ladder standard (Elpis Biotech). Production of bacteriochlorophyll $a$ was determined by pigment absorption spectrum analysis (Lafay et al., 1995). Strain $\mathrm{HJ} 50^{\mathrm{T}}$ was cultivated aerobically in the dark at $35{ }^{\circ} \mathrm{C}$ in MB. Pigments were extracted from the culture in the dark at $4{ }^{\circ} \mathrm{C}$ with $10 \mathrm{ml}$ methanol. The presence of pigments was determined by visible spectrophotometry (300-900 nm) with a Biochrom Libra S21 spectrophotometer.

By using the PCR amplification approach, a specific 229 bp product, indicative of the presence of the bacterial photosynthetic reaction centre $M$ subunit, was clearly amplified from strains of Rva. tolerans and Rva. mucosus (Allgaier et al., 2003; Biebl et al., 2005). In contrast, this specific PCR product was not amplified from strain $\mathrm{H} J 50^{\mathrm{T}}$ and bacteriochlorophyll $a$ was not detected.

For cellular fatty acid analysis, strain $\mathrm{HJ} 50^{\mathrm{T}}$ and type strains of some Roseovarius species were cultivated for 3 days on MA. Cellular fatty acids were saponified, methylated and extracted according to the protocol of the Sherlock Microbial Identification system (MIDI). The fatty acids were then analysed by GC (Hewlett Packard 6890 ) using the Microbial Identification software package (Sasser, 1990).

There were some differences between the fatty acid methyl ester composition of $\mathrm{HJ}^{5} \mathrm{O}^{\mathrm{T}}$ and those of type strains of members of the genus Roseovarius. Strain $\mathrm{HJ}^{\mathrm{T}} \mathrm{T}^{\mathrm{T}}$ and other members of the genus Roseovarius contained predominantly $\mathrm{C}_{18: 1} \omega 7 c / \omega 9 t / \omega 12 t$ (summed feature 7 ), followed by 
Table 1. Phenotypic characteristics of strain $\mathrm{HJ}_{50}^{\top}$ and related Roseovarius species

Strains: 1, strain $\mathrm{HJ}_{50}^{\mathrm{T}}$; 2, Rva. nubinhibens DSM 15170 ${ }^{\mathrm{T}}$; 3, Rva. tolerans DSM 11457 ${ }^{\mathrm{T}}$; 4, Rva. crassostreae DSM 16950 ${ }^{\mathrm{T}}$; 5, Rva. mucosus DSM $17069^{\mathrm{T}} ;$ 6, Rva. aestuarii KCTC $22174^{\mathrm{T}}$ (data from Yoon et al., 2008). All data are from this study except where indicated. All strains were positive for catalase and oxidase, but negative for Gram staining and citrate assimilation. +, Positive; w, weakly positive; v, variable; -, negative; NA, no data available. puf $M$ encodes a key polypeptide in the bacterial photosynthetic reaction centre $\mathrm{M}$ subunit.

\begin{tabular}{|c|c|c|c|c|c|c|}
\hline Characteristic & 1 & 2 & 3 & 4 & 5 & 6 \\
\hline Cell morphology & Rod to ovoid & Short rod & Short rod & Rod to ovoid & Short rods & Rod to ovoid \\
\hline Flagella & - & NA & $-{ }^{a \star}$ & $+{ }^{b}$ & $-^{c}$ & + \\
\hline Motility & - & - & W & + & - & + \\
\hline \multicolumn{7}{|l|}{ Growth temperature $\left({ }^{\circ} \mathrm{C}\right)$} \\
\hline Range & $10.0-45.0$ & $10.0-40.0^{d}$ & $3.0-43.5^{a}$ & $19.0-40.0^{b}$ & $20.0-40.0^{c}$ & $10-37$ \\
\hline Optimum & 35.0 & $30.0^{d}$ & $8.0-33.5^{a}$ & $34.0^{b}$ & $31.0^{c}$ & 30.0 \\
\hline \multicolumn{7}{|l|}{ Growth in sea salts $(\%)$} \\
\hline Range & $0.5-20.0$ & $0.5-12.5$ & $1.0-12.5$ & $1.0-6.0$ & $1.0-6.0$ & $0.5-7.0$ \\
\hline Optimum & $3.0-4.0$ & $2.0-5.0$ & $4.0-5.0$ & $2.0-4.0$ & $1.0-3.0$ & NA \\
\hline pufM gene & - & - & + & - & + & NA \\
\hline Urease & + & - & + & + & - & - \\
\hline$\beta$-Galactosidase & - & - & + & + & - & - \\
\hline Acid production from glucose & + & - & - & - & - & - \\
\hline \multicolumn{7}{|l|}{ Assimilation of: } \\
\hline Salicin & - & - & + & + & + & - \\
\hline Propionate & + & - & - & - & - & NA \\
\hline 2-Ketogluconate & + & - & + & + & + & NA \\
\hline 3-Hydroxybutyrate & + & - & - & - & - & NA \\
\hline L-Arabinose & + & $\mathrm{V}$ & + & + & + & - \\
\hline Maltose & + & $\mathrm{V}$ & $\mathrm{V}$ & + & $\mathrm{V}$ & - \\
\hline D-Mannose & + & - & + & + & + & - \\
\hline Rhamnose & $\mathrm{w}$ & - & $\mathrm{w}$ & $\mathrm{w}$ & + & NA \\
\hline Acetate & - & - & $\mathrm{w}$ & $\mathrm{w}$ & + & + \\
\hline DNA G $+\mathrm{C}$ content $(\mathrm{mol} \%)$ & $59.0 \pm 0.1$ & 66.0 & $62.2-63.8$ & 59.0 & $60.9-62.9$ & 58.6 \\
\hline
\end{tabular}

${ }^{\star}$ Data taken from: a, Labrenz et al. (1999); b, Boettcher et al. (2005); c, Biebl et al. (2005); d, González et al. (2003).

$\mathrm{C}_{16: 0}$ (Table 2). In addition, $\mathrm{C}_{19: 0}$ cyclo $\omega 8$ c, an unknown fatty acid (ECL 18.079), $\mathrm{C}_{12: 0}$ and $\mathrm{C}_{12: 0} 3-\mathrm{OH}$ also occurred in the novel isolate. Strain $\mathrm{HJ} 50^{\mathrm{T}}$ differed from the other Roseovarius species in that it lacked iso- $\mathrm{C}_{18: 0}$, which is found in Rva. tolerans and Rva. mucosus, and summed feature 3, which is found in Rva. nubinhibens and Rva. crassostreae.

Isoprenoid quinones were extracted with chloroform/ methanol $(2: 1, \mathrm{v} / \mathrm{v})$ and purified by TLC on Merck silica gel $60 \mathrm{~F}_{254}$ plates $(20 \times 20 \mathrm{~cm}, 0.5 \mathrm{~cm}$ thick $)$ using a mixture of petroleum benzene and diethyl ether $(85: 15, \mathrm{v} /$ v) as the developing solvent. Spots were scraped off and then analysed by HPLC as described previously (Collins \& Jones, 1981; Shin et al., 1996). Polar lipids were extracted and examined by two-dimensional TLC according to the method of Tindall (1990) (see Supplementary Fig. S1 in IJSEM Online). The major isoprenoid quinone was ubiquinone-10, as observed in Rva. tolerans (Labrenz et al., 1999) and Rva. mucosus (Biebl et al., 2005). Strain $\mathrm{HJ} 50^{\mathrm{T}}$ contained diphosphatidylglycerol as well as phosphatidylglycerol, phosphatidylethanolamine and phosphatidylcholine, as shown previously in Rva. tolerans (Labrenz et al., 1999) and Rva. mucosus (Biebl et al., 2005). In addition, cells of strain $\mathrm{HJ}^{\mathrm{T}} \mathrm{T}^{\mathrm{T}}$ contained unidentified lipids. These results show clear differences in polar lipid composition compared with other members of the Rhodobacteraceae, such as Marinovum algicola, Leisingera methylohalidivorans, Ruegeria atlantica, Roseobacter litoralis and Phaeobacter inhibens (Labrenz et al., 1998; Martens et al., 2006). Taken together, the major fatty acids and polar lipid data indicate that strain $\mathrm{HJ} 50^{\mathrm{T}}$ belongs to the genus Roseovarius.

For phylogenetic analysis of strain $\mathrm{HJ} 50^{\mathrm{T}}$, DNA was extracted using a commercial genomic DNA extraction kit (Solgent). The 16S rRNA gene was amplified from the chromosomal DNA using the universal bacterial primer set 27F (5'-AGAGTTTGATCMTGGCTCAG-3') and 1492R (5'-TACGGYTACCTTGTTACGACTT- $\left.3^{\prime}\right)$ and purified PCR products were sequenced by Solgent, Daejeon, South Korea (Park et al., 2006). Full 16S rRNA gene sequences were compiled using SEQMAN software (DNASTAR). The 16S rRNA gene sequences of related taxa were obtained from GenBank. Multiple alignments were performed with CLUSTAL_X (Thompson et al., 1997). Gaps 
Table 2. Fatty acid compositions of strain $\mathrm{HJ} 50^{\top}$ and the type strains of Roseovarius species

Strains: 1, strain $\mathrm{HJ}_{50}^{\mathrm{T}}$; 2, Rva. nubinhibens DSM $15170^{\mathrm{T}} ; 3$, Rva. tolerans DSM 11457 ${ }^{\mathrm{T}}$; 4, Rva. crassostreae DSM 16950 ${ }^{\mathrm{T}}$; , Rva. mucosus DSM $17069^{\mathrm{T}}$; 6, Rva. aestuarii KCTC $22174^{\mathrm{T}}$ (data from Yoon et al., 2008). Data are from this study unless indicated. Values are percentages of total fatty acids; values less than $0.5 \%$ are not shown. Equivalent chain lengths (ECL) are given for unknown fatty acids.

\begin{tabular}{|c|c|c|c|c|c|c|}
\hline Fatty acids & 1 & 2 & 3 & 4 & 5 & 6 \\
\hline \multicolumn{7}{|l|}{ Saturated } \\
\hline $\mathrm{C}_{12: 0}$ & 5.85 & 6.94 & & & 6.11 & 5.10 \\
\hline $\mathrm{C}_{16: 0}$ & 10.35 & 12.46 & 14.29 & 10.46 & 8.12 & 16.20 \\
\hline $\mathrm{C}_{18: 0}$ & 2.90 & 1.10 & 2.32 & 1.58 & 1.20 & 1.00 \\
\hline \multicolumn{7}{|l|}{ Branched-chain } \\
\hline iso- $\mathrm{C}_{18: 0}$ & & & 2.08 & & 3.34 & \\
\hline \multicolumn{7}{|l|}{ Hydroxy } \\
\hline $\mathrm{C}_{12: 0} 2-\mathrm{OH}$ & & & & & 1.10 & \\
\hline $\mathrm{C}_{16: 0} 2-\mathrm{OH}$ & 0.95 & & 1.59 & 2.81 & 5.42 & \\
\hline $\mathrm{C}_{10: 0} 3-\mathrm{OH}$ & 0.67 & & & 3.45 & 1.57 & \\
\hline $\mathrm{C}_{12: 0} 3-\mathrm{OH}$ & 5.55 & 4.97 & 3.39 & & & 5.30 \\
\hline $\mathrm{C}_{12: 1} 3-\mathrm{OH}$ & 2.73 & & & & 3.80 & \\
\hline $\mathrm{C}_{16: 0} 3-\mathrm{OH}$ & & & & 0.63 & & \\
\hline \multicolumn{7}{|l|}{ Cyclo } \\
\hline $\mathrm{C}_{19: 0}$ cyclo $\omega 8 c$ & 9.18 & 17.43 & & & 9.52 & 1.50 \\
\hline \multicolumn{7}{|l|}{ Summed features ${ }^{\star}$} \\
\hline 3 & & 1.13 & & 9.32 & & \\
\hline 4 & & & & 2.07 & 0.90 & 0.60 \\
\hline 7 & 52.60 & 47.98 & 69.79 & 68.92 & 57.11 & 68.00 \\
\hline 9 & & & & & 0.93 & \\
\hline \multicolumn{7}{|l|}{ Methyl ester } \\
\hline $\mathrm{C}_{19: 0}$ 10-methyl & & & & 0.75 & & \\
\hline \multicolumn{7}{|l|}{ Unknown } \\
\hline 11.798 & 0.91 & 1.24 & & & 0.86 & \\
\hline 15.283 & & 6.75 & & & & \\
\hline 18.079 & 8.32 & & 6.54 & & & \\
\hline
\end{tabular}

*Summed features represent groups of two of three fatty acids that cannot be separated by GLC with the MIDI system. Summed feature $3, \mathrm{C}_{14: 0} 3-\mathrm{OH} /$ iso- $\mathrm{C}_{16: 1} \mathrm{I}$ (double bond position indicated by a capital letter is unknown); summed feature $4, \mathrm{C}_{16: 1} \omega 7 \mathrm{cl}$ iso- $\mathrm{C}_{15: 0} 2-\mathrm{OH}$; summed feature $7, \mathrm{C}_{18: 1} \omega 7 \mathrm{c} / \omega 9 \mathrm{t} / \omega 12 t$; summed feature 9 , unknown fatty acids ECL 18.846/18.858.

were edited using BIOEDIT (Hall, 1999). Evolutionary distances were calculated using Kimura's two-parameter model (Kimura, 1980). The phylogenetic tree was constructed by the neighbour-joining (Saitou \& Nei, 1987), maximum-parsimony (Kluge \& Farris, 1969) and maximum-likelihood (Felsenstein, 1981) methods in MEGA3 (Kumar et al., 2004) or the PHYLIP package (Felsenstein, 1993) with bootstrap values based on 1000 replications (Felsenstein, 1985).

To determine the phylogenetic position of strain $\mathrm{HJ} 50^{\mathrm{T}}$, its 16S rRNA gene sequence (1430 nt) was compared with those of type strains of members of the Alphaproteobacteria retrieved from GenBank. Phylogenetic analyses based on neighbour-joining, maximum-parsimony and maximumlikelihood analysis showed that strain $\mathrm{HJ} 50^{\mathrm{T}}$ could be placed within the evolutionary radiation enclosed by the genus Roseovarius (Fig. 2). Analysis of specific signature nucleotides at several positions in the secondary structure of the 16S rRNA gene can be used to differentiate the Rva. nubinhibens/Rva. crassostreae cluster from the Rva. tolerans/ Rva. mucosus cluster (Biebl et al., 2005). The helical regions of strain $\mathrm{HJ}_{50}{ }^{\mathrm{T}}$ at positions $240-242 / 284-286$ and $113-$ $115 / 312-314$ were characterized as UAG/CUA and GUU/ AAC, respectively, which were the same as in Rva. crassostreae, Rva. nubinhibens and Rva. aestuarii. However, nucleotides at positions 577-580/761-764 were GCAC/GUGC, which were the same as in Rva. tolerans and Rva. mucosus. 16S rRNA gene sequence similarities between strain $\mathrm{HJ} 50^{\mathrm{T}}$ and type strains of members of the genus Roseovarius ranged from 94.1 to $96.3 \%$.

For the measurement of the chromosomal DNA G+C content, the extracted genomic DNA was degraded enzymically into nucleosides and the $\mathrm{G}+\mathrm{C}$ content was determined as described by Mesbah et al. (1989) using reversed-phase HPLC. The DNA G+C content of $\mathrm{HJ} 50^{\mathrm{T}}$ was $59.0 \pm 0.1 \mathrm{~mol} \%(n=3)$. 


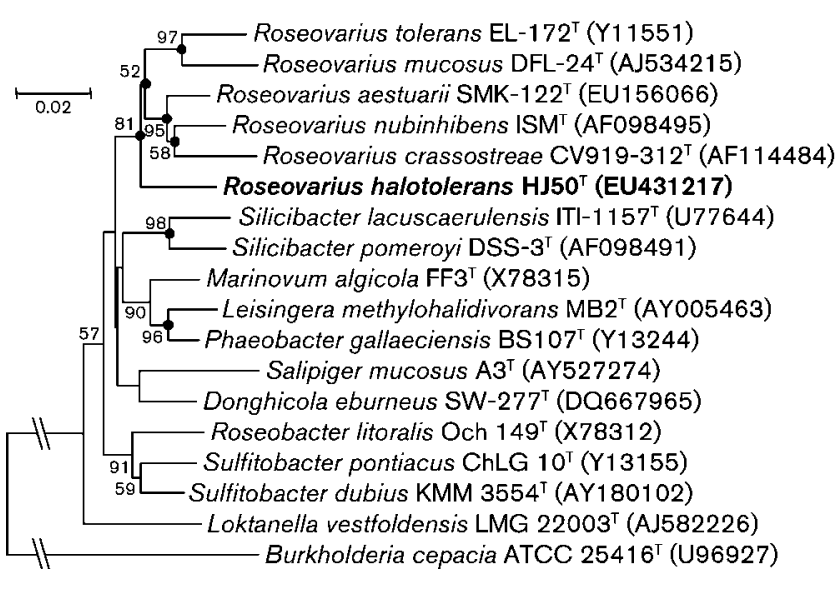

Fig. 2. Neighbour-joining tree based on $16 \mathrm{~S}$ rRNA gene sequence comparisons showing the phylogenetic relationships of strain $\mathrm{HJ}_{50}{ }^{\top}$ within the Alphaproteobacteria. Bootstrap values (expressed as percentages of 1000 replications) greater than $50 \%$ are given at nodes. Filled circles indicate that the corresponding nodes were also recovered in trees generated with the maximum-likelihood and maximum-parsimony algorithms. The sequence of Burkholderia cepacia ATCC $25416^{\top}$ was used as an outgroup and GenBank accession numbers are given in parentheses. Bar, 2 substitutions per 100 nucleotide positions.

DNA-DNA hybridization experiments were performed between $\mathrm{HJ} 50^{\mathrm{T}}$ and four type strains of members of the genus Roseovarius using photobiotin-labelled DNA probes and microdilution wells as described by Ezaki et al. (1989). Hybridization was performed with five replications for each sample. The highest and lowest values obtained for each sample were excluded and the means of the remaining three values are quoted as DNA relatedness values.

DNA-DNA relatedness values of strain $\mathrm{HJ} 50^{\mathrm{T}}$ were 1.3 , 3.3, 5.3 and $24.6 \%$ with Rva. tolerans DSM $11457^{\mathrm{T}}$, Rva. crassostreae DSM $16950^{\mathrm{T}}$, Rva. nubinhibens DSM $15170^{\mathrm{T}}$ and Rva. mucosus DSM $17069^{\mathrm{T}}$, respectively.

Therefore, based on data from this polyphasic study, strain $\mathrm{HJ} 50^{\mathrm{T}}$ should be classified in the genus Roseovarius as a representative of a novel species, for which the name Roseovarius halotolerans sp. nov. is proposed.

\section{Description of Roseovarius halotolerans sp. nov.}

Roseovarius halotolerans (ha.lo.to'le.rans. Gr. n. hals salt; L. part. adj. tolerans tolerating; N.L. part. adj. halotolerans salt-tolerating, referring to the organism's ability to tolerate high salt concentrations).

Cells are Gram-reaction-negative, non-motile, aerobic and oval- to rod-shaped $(0.5-0.8 \mu \mathrm{m}$ in diameter and $1.3-$ $3.0 \mu \mathrm{m}$ long), frequently with unequal ends before and after division. Colonies are opaque, white to faintly pink in the centre, circular and glistening. Optimal growth temperature is $35{ }^{\circ} \mathrm{C}$. Optimal $\mathrm{pH}$ for growth is 7.5.
Optimum growth occurs in the presence of 3-4\% sea salts; tolerates up to $20 \%(\mathrm{w} / \mathrm{v})$ sea salts. $\beta$-Galactosidase and arginine dihydrolase are not detected. Utilizes D-glucose, Larabinose, L-rhamnose, sucrose, D-mannose, maltose, Dsorbitol, propionate, 2-ketogluconate, 3-hydroxybutyrate and DL-lactate, but not D-ribose, melibiose, L-fucose, Dmannitol, inositol, caprate, valerate, citrate, 4-hydroxybenzoate, itaconate, suberate, malonate, acetate, 5-ketogluconate, 3-hydroxybenzoate, phenylacetate, malate, adipate, salicin, glycogen, $\mathrm{N}$-acetylglucosamine, L-histidine, L-alanine or L-serine. Other characteristics are given in Table 1. Does not have pufM or produce bacteriochlorophyll $a$. Phosphatidylglycerol, phosphatidylcholine, phosphatidylethanolamine and diphosphatidylglycerol are present. The principal fatty acid is summed feature $7\left(\mathrm{C}_{18: 1} \omega 7 \mathrm{c} / \omega 9 \mathrm{t}\right)$ $\omega 12 t)$. The DNA G+C content of the type strain is $59.0 \pm 0.1 \mathrm{~mol} \%$.

The type strain is $\mathrm{HJ} 50^{\mathrm{T}}\left(=\mathrm{KCTC} 22224^{\mathrm{T}}=\mathrm{LMG} 24468^{\mathrm{T}}\right)$, isolated from deep water of the East Sea, South Korea.

\section{Acknowledgements}

This work was supported by the Korea Research Foundation Grant funded by the Korean Government (MOEHRD) (The Regional Research Universities Program/Chungbuk BIT Research-Oriented University Consortium).

\section{References}

Achenbach, L. A., Carey, J. \& Madigan, M. T. (2001). Photosynthetic and phylogenetic primers for detection of anoxygenic phototrophs in natural environments. Appl Environ Microbiol 67, 2922-2926.

Allgaier, M., Uphoff, H., Felske, A. \& Wagner-Döbler, I. (2003). Aerobic anoxygenic photosynthesis in Roseobacter clade bacteria from diverse marine habitats. Appl Environ Microbiol 69, 5051-5059.

Biebl, H., Allgaier, M., Lunsdörf, H., Pukall, R., Tindall, B. J. \& Wagner-Döbler, I. (2005). Roseovarius mucosus sp. nov., a member of the Roseobacter clade with trace amounts of bacteriochlorophyll $a$. Int J Syst Evol Microbiol 55, 2377-2383.

Boettcher, K. J., Geaghan, K. K., Maloy, A. P. \& Barber, B. J. (2005). Roseovarius crassostreae sp. nov., a member of the Roseobacter clade and the apparent cause of juvenile oyster disease (JOD) in cultured Eastern oysters. Int J Syst Evol Microbiol 55, 1531-1537.

Buck, J. D. (1982). Nonstaining (KOH) method for determination of gram reactions of marine bacteria. Appl Environ Microbiol 44, 992993.

Collins, M. D. \& Jones, D. (1981). Distribution of isoprenoid quinone structural types in bacteria and their taxonomic implications. Microbiol Rev 45, 316-354.

Ezaki, T., Hashimoto, Y. \& Yabuuchi, E. (1989). Fluorometric deoxyribonucleic acid-deoxyribonucleic acid hybridization in microdilution wells as an alternative to membrane filter hybridization in which radioisotopes are used to determine genetic relatedness among bacterial strains. Int J Syst Bacteriol 39, 224-229.

Felsenstein, J. (1981). Evolutionary trees from DNA sequences: a maximum likelihood approach. J Mol Evol 17, 368-376.

Felsenstein, J. (1985). Confidence limit on phylogenies: an approach using the bootstrap. Evolution 39, 783-791. 
Felsenstein, J. (1993). PHYLIP (phylogeny inference package), version 3.5. Distributed by the author. Department of Genome Sciences, University of Washington, Seattle, USA.

González, J. M., Covert, J. S., Whitman, W. B., Henriksen, J. R., Mayer, F., Scharf, B., Schmitt, R., Buchan, A., Fuhrman, J. A. \& other authors (2003). Silicibacter pomeroyi sp. nov. and Roseovarius nubinhibens sp. nov., dimethylsulfoniopropionate-demethylating bacteria from marine environments. Int J Syst Evol Microbiol 53, 1261-1269.

Hall, T. A. (1999). BioEdit: a user-friendly biological sequence alignment editor and analysis program for Windows 95/98/NT. Nucleic Acids Symp Ser 41, 95-98.

Kimura, M. (1980). A simple method for estimating evolutionary rates of base substitutions through comparative studies of nucleotide sequences. J Mol Evol 16, 111-120.

Kluge, A. G. \& Farris, J. S. (1969). Quantitative phyletics and the evolution of anurans. Syst Zool 18, 1-32.

Kumar, S., Tamura, K. \& Nei, M. (2004). MEGA3: integrated software for molecular evolutionary genetics analysis and sequence alignment. Brief Bioinform 5, 150-163.

Labrenz, M., Collins, M. D., Lawson, P. A., Tindall, B. J., Braker, G. \& Hirsch, P. (1998). Antarctobacter heliothermus gen. nov., sp. nov., a budding bacterium from hypersaline and heliothermal Ekho Lake. Int J Syst Bacteriol 48, 1363-1372.

Labrenz, M., Collins, M. D., Lawson, P. A., Tindall, B. J., Schumann, P. \& Hirsch, P. (1999). Roseovarius tolerans gen. nov., sp. nov., a budding bacterium with variable bacteriochlorophyll a production from hypersaline Ekho Lake. Int J Syst Bacteriol 49, 137-147.

Lafay, B., Ruimy, R., Rausch de Traubenberg, C., Breittmayer, V., Gauthier, M. J. \& Christen, R. (1995). Roseobacter algicola sp. nov., a new marine bacterium isolated from the phycosphere of the toxinproducing dinoflagellate Prorocentrum lima. Int J Syst Bacteriol 45, 290-296.

Martens, T., Heidorn, T., Pukall, R., Simon, M., Tindall, B. J. \& Brinkhoff, T. (2006). Reclassification of Roseobacter gallaeciensis
Ruiz-Ponte et al. 1998 as Phaeobacter gallaeciensis gen. nov., comb. nov., description of Phaeobacter inhibens sp. nov., reclassification of Ruegeria algicola (Lafay et al. 1995) Uchino et al. 1999 as Marinovum algicola gen. nov., comb. nov., and emended descriptions of the genera Roseobacter, Ruegeria and Leisingera. Int J Syst Evol Microbiol 56, 1293-1304.

Mesbah, M., Premachandran, U. \& Whitman, W. B. (1989). Precise measurement of the $\mathrm{G}+\mathrm{C}$ content of deoxyribonucleic acid by high-performance liquid chromatography. Int J Syst Bacteriol 39, 159-167.

Park, J. W., Oh, Y. S., Lim, J. Y. \& Roh, D. H. (2006). Isolation and characterization of cold-adapted strains producing $\beta$-galactosidase. J Microbiol 44, 396-402.

Saitou, N. \& Nei, M. (1987). The neighbor-joining method: a new method for reconstructing phylogenetic trees. Mol Biol Evol 4, 406425.

Sasser, M. (1990). Identification of bacteria by gas chromatography of cellular fatty acids, MIDI Technical Note 101. Newark, DE: MIDI Inc.

Shin, Y. K., Lee, J.-S., Chun, C. O., Kim, H.-J. \& Park, Y.-H. (1996). Isoprenoid quinone profiles of the Leclercia adecarboxylata KCTC $1036^{\mathrm{T}}$. J Microbiol Biotechnol 6, 68-69.

Thompson, J. D., Gibson, T. J., Plewniak, F., Jeanmougin, F. \& Higgins, D. G. (1997). The CLUSTAL_X windows interface: flexible strategies for multiple sequence alignment aided by quality analysis tools. Nucleic Acids Res 25, 4876-4882.

Tindall, B. J. (1990). Lipid composition of Halobacterium lacusprofundi. FEMS Microbiol Lett 66, 199-202.

Yoon, J.-H., Kang, S.-J. \& Oh, T.-K. (2008). Roseovarius aestuarii sp. nov., isolated from a tidal flat of the Yellow Sea in Korea. Int J Syst Evol Microbiol 58, 1198-1202.

Zeng, Y. \& Jiao, N. (2007). Source environment feature related phylogenetic distribution pattern of anoxygenic photosynthetic bacteria as revealed by pufM analysis. J Microbiol 45, 205-212. 